\title{
A study of calcium release from rat liver microsomes by thapsigargicin induction"
}

\author{
Elif ÖZTETIK
}

Department of Biology, Science Faculty, Anadolu University, Eskisehir / Turkey

\begin{abstract}
Summary: The primary aim of the study was to test the influences of thapsigargicin in releasing $\mathrm{Ca}^{2+}$ from the intracellular $\mathrm{Ca}^{2+}$ stores and comparing it with the effects of thapsigargin. In this study, the effect of tumour promoter thapsigargicin on intracellular $\mathrm{Ca}^{2+}$ has been described. Therefore, rat liver endoplasmic reticulum subcellular fractions (microsomes) were employed and $\mathrm{Ca}^{2+}$ movements measured by spectrofluorimeter. Fluo-3 studies were used to follow $\mathrm{Ca}^{2+}$ release in experiments with microsomes. When results are evaluated, it has been concluded that like thapsigargin, thapsigargicin has the ability of discharging the intracellular $\mathrm{Ca}^{2+}$ stores, increasing the intracellular free $\mathrm{Ca}^{2+}$ concentration $\left(\left[\mathrm{Ca}^{2+}\right] \mathrm{i}\right)$ and being a potent and specific inhibitor of the ER $\mathrm{Ca}^{2+}$-ATPase.

Key words: $\mathrm{Ca}^{2+}$ release, intracellular stores, SERCA ATPases, spectroscopy, thapsigargin (TG), thapsigargicin (TGC).
\end{abstract}

\section{Tapsigargisin indüksiyonu ile sıçan karaciğer mikrozomlarından kalsiyum salınımı üzerine bir çalışma}

Özet: $\mathrm{Bu}$ çalışmanın ana amacı hücre içindeki $\mathrm{Ca}^{2+}$ depolarından $\mathrm{Ca}^{2+}$ salınımına tapsigargisinin etkisinin test edilmesi ve bunun tapsigargin etkisi ile karşılaştırılmasıdır. Çalışmada tümor promotörü tapsigargisinin hücre içindeki $\mathrm{Ca}^{2+} \mathrm{a}$ etkileri tanımlanmıştır. $\mathrm{Bu}$ nedenle, sıçan endoplazmik retikulum subsellüler (hücrealtı) fraksiyonları (mikrozomlar) kullanılmış ve $\mathrm{Ca}^{2+}$ hareketleri spektrofluorimetre ile ölçülmüştür. Mikrozomlardaki $\mathrm{Ca}^{2+}$ salınımı Fluo-3 çalışmaları ile takip edilmiştir. Elde edilen

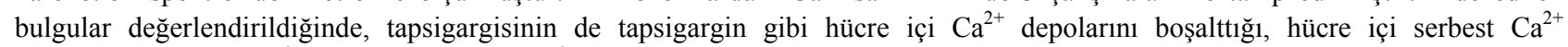
konsantrasyonunu ([Ca $\left.{ }^{2+}\right]$ i) arttırdığı ve ER $\mathrm{Ca}^{2+}$-ATPaz için güçlü ve özgül bir inhibitör olduğu kanısına varılmıştır.

Anahtar sözcükler: $\mathrm{Ca}^{2+}$ salınımı, hücreiçi depolar, SERCA ATPaz, spektroskopi, tapsigargin (TG), tapsigargisin (TGC).

\section{Introduction}

The survival, specialized functions and reproduction of eukaryotic cells and many prokaryotes requires $\mathrm{Ca}^{2+}$ in the medium bathing the cells. Intracellular free $\mathrm{Ca}^{2+}$ concentrations $\left(\left[\mathrm{Ca}^{2+}\right] \mathrm{i}\right)$ and the concentration of $\mathrm{Ca}^{2+}$ in the intracellular stores [(endoplasmic reticulum (ER) and its muscle counterpart, sarcoplasmic reticulum (SR)] are controlled by the network of $\mathrm{Ca}^{2+}$ channels and transporters (pumps). $\mathrm{Ca}^{2+}$-ATPase pumps are one of those recognised mechanisms that are found in the plasma membrane (Plasma membrane $\mathrm{Ca}^{2+}$-ATPase: PMCA), in the ER/SR membrane (sarco-endoplasmic $\mathrm{Ca}^{2+}$-ATPase: SERCA), in the Golgi and in the nuclear envelope (in yeasts, they are also found in other organelles). They export $\mathrm{Ca}^{2+}$ to the ER/SR lumen or to the extracellular spaces (2).

The SERCA ATPase transports $\mathrm{Ca}^{2+}$ ions into the SR with a stoichiometry of $2 \mathrm{Ca}^{2+}: 1 \mathrm{ATP}$, which suggests a major mechanistic difference to the PMCA, as the latter works with a $1 \mathrm{Ca}^{2+}: 1$ ATP stoichiometry (21). The understanding of the molecular mechanism of the SERCA pump has been greatly advanced by the recent solution of its crystal structure at $2.6 \AA$ resolution (29) and the published structure indeed has two $\mathrm{Ca}^{2+}$ ions bound to the transmembrane domain (3). Although both pumps (PMCAs and SERCAs) have ten putative transmembrane-spanning domains, homology between the two classes is unexpectedly low (18).

On the other hand, according to the findings of Dawson (8), it thus appears that the SR and ER $\mathrm{Ca}^{2+}$ ATPases are probably not identical, but there are certainly great similarities between them. In the following years, the ER $\mathrm{Ca}^{2+}$ transport ATPase of blood platelets were compared with the $\mathrm{Ca}^{2+}$-ATPase of SR skeletal muscle. The stoichiometry between $\mathrm{Ca}^{2+}$ ion released and ATP synthesized by platelet $\mathrm{Ca}^{2+}$-ATPase was found to be 1 , while that of skeletal muscle was 2 . The possibility was discussed that the differences

\footnotetext{
* Summarized from the MSc dissertation of the author. The study was carried out in accordance with the ethical rules and recommendations.
} 
observed between the two transport systems is related to the distinct amino acid sequences of the enzymes (1).

There are a number of different chemical compounds which inhibit specifically the SERCA ATPases, like thapsigargin (TG), thapsigargicin (TGC), cyclopiazonic acid (CPA), and 2,5-di(tert-butyl)hydroquinone (DBHQ) (Figure 1). From those, CPA is one of the toxic metabolites produced by the molds Penicillium cyclopium and Aspergillus flavus (13). Goeger et al. (12) found that CPA is a potent inhibitor of $\mathrm{Ca}^{2+}$ sequestration and ATPase activity in SR of rat skeletal muscle and suggested that this inhibition accounts for CPA toxicity. Hydroquinones are important industrial chemicals (20) and DBHQ was found to inhibit ATP-dependent $\mathrm{Ca}^{2+}$ uptake by liver microsomes. However, it was ineffective on $\mathrm{Ca}^{2+}$ transport by mitochondria or plasma membrane (19), so its mechanism quite similar to that of TG (30) (see below).

Today, the known range of collectively termed 'thapsigargins family' found in Thapsia genus had reached 16 members (including TG and TGC) and these natural compounds fall into two series of molecules differentiated by the presence of an oxygen substituent at the $\mathrm{C} 2$ position (15). TG, is a tumor-promoting sesquiterpene lactone, isolated from the root of the umbelliferous plant Thapsia garganica L. $(5,24)$ and is commonly used as a probe for intracellular $\mathrm{Ca}^{2+}$ storage and release processes. From previous studies, the general characteristics of cellular TG's on $\mathrm{Ca}^{2+}$ responses can be summarized as follows; (i) a $\left[\mathrm{Ca}^{2+}\right] \mathrm{i}$ rise that is slower than that elicited by hormonal stimulation, (ii) no concomitant breakdown of inositolphospholipids with the production of inositol phosphates $(14,26)$, and (iii) an
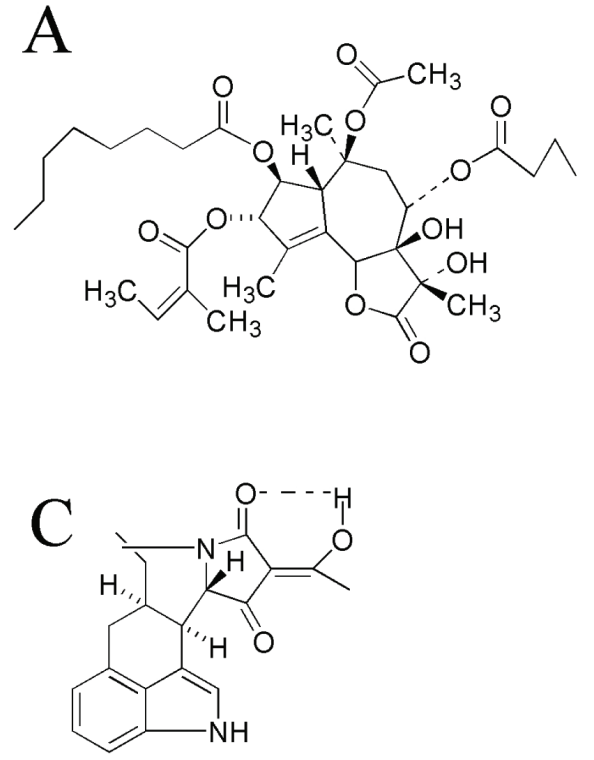

initiation of $\left[\mathrm{Ca}^{2+}\right] \mathrm{i}$ rise by release of intracellular sequestered $\mathrm{Ca}^{2+}$.

According to Christensen et al. (6), the activity of $\mathrm{TG}$ originates mainly from the ester groups at $\mathrm{C} 3, \mathrm{C} 8$ and $\mathrm{C} 10$ positions and also from the lactose ring substituents. Comparison of the structures of TG and TGC (MWs are; 652,79 and 622,70 respectively) reveals that the only difference between the two compounds is the presence of four methylene groups in the acyl group of TGC, whereas six are present in TG (Figure 1). By considering their close structure to each other and their origin of same umbelliferous plant, the main aim of this study was to show the effects of TGC, as SERCA ATPase inhibitor, on $\mathrm{Ca}^{2+}$ movements by using rat liver microsomes and comparing its effects with other well known SERCA ATPase inhibitor TG.

\section{Materials and Methods}

Animals, chemicals, equipments: Healthy, male Wistar albino rats weighing 200-250 g. were used in this study. Fluo-3 pentammonium salt (a membrane impermeable $\mathrm{Ca}^{2+}$ indicator) was purchased from Molecular Probes Inc. (Eugene, OR, U.S.A). Phosphocreatine, creatine phosphokinase, A23187 (a calcium ionophore), EGTA (ethylene glycol-bis(beta-aminoethylether)-N,N,N',N'tetraacetate) and BSA (bovine serum albumin) were purchased from Sigma Chemical Co., Poole, Dorset. U.K. ATP and DTT (dithiothreitol) were from B.C.L. (Lewes, Sussex, UK). Thapsigargicin (TGC) was purchased from LC Laboratories (Nottingham, UK). All other chemicals were of analytical grade and were obtained from commercial sources at the highest grade of purity available.

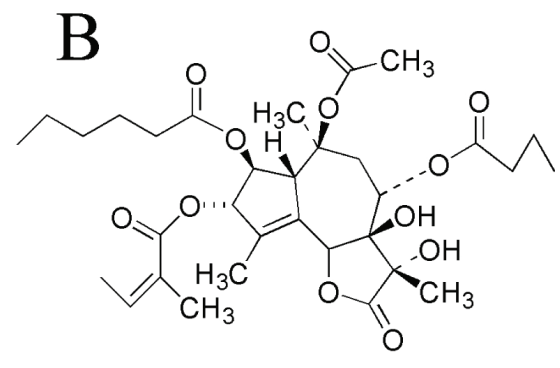<smiles>CC(C)(C)c1cc(O)c(C(C)(C)C)cc1O</smiles>

Figure 1. Structures of $\mathrm{Ca}^{2+}$-ATPase inhibitors

A. Thapsigargin (TG), B. Thapsigargicin (TGC), C. Cyclopiazonic acid (CPA), D. 2,5-Di(tert-butyl)hydroquinone (DBHQ)

Şekil 1. $\mathrm{Ca}^{2+}$-ATPaz inhibitörlerinin yapıları

A. Tapsigargin (TG), B. Tapsigargisin (TGC), C. Siklopiazonik asit (CPA), D. 2,5-Di(tert-butil)hidrokinon (DBHQ) 
Spectrophotometric studies employed a Shimadzu RF-5000 fluorimeter. The fluorimeter was used under mode of operation of single wavelength spectrofluorimetry for $\mathrm{Ca}^{2+}$ release experiments by using Fluo-3 pentammonium salt. The commercially available Shimadzu RF-5000 fluorimeter has a minimum mixing time of $1 \mathrm{~s}$.

Preparation of rat liver endoplasmic reticulum vesicles (microsomes): Microsomes were prepared from the livers of fed 200-250 g. male Wistar albino rats according to Dawson (8) and Reinhart and Bygrave (9) with some modifications. The liver was dissected and immidiately suspended in $100 \mathrm{ml}$ of ice-cold homogenization buffer $(250 \mathrm{mM}$ sucrose, $5 \mathrm{mM}$ Hepes/KOH, pH 7.0, 1 mM EGTA and $1 \mathrm{mM}$ DTT). All relevant steps were carried out at $4^{\circ} \mathrm{C}$. The liver was chopped and homogenized by six strokes of a Dounce homogenizer $(0.2 \mathrm{~mm}$ radial clearance). This homogenate was centrifuged at $3000 \mathrm{~g}$ for $5 \mathrm{~min}$. in a Sorvall RC-5B centrifuge and the supernatant was recentrifuged at $8000 \mathrm{~g}$ for $10 \mathrm{~min}$. to give a pellet termed the mitochondrial fraction. Microsomes were then prepared from the resulting supernatant by centrifugation at $18000 \mathrm{~g}$ for $20 \mathrm{~min}$. The pellet was resuspended in a second buffer $(250 \mathrm{mM}$ sucrose, $5 \mathrm{mM}$ Hepes $/ \mathrm{KOH}$, pH 7.0, $10 \mathrm{mM} \mathrm{KCl}$ and $1 \mathrm{mM} \mathrm{DTT})$ and centrifuged (18000 $g, 20 \mathrm{~min}$ ). This final spin produced a microsomal pellet which was resuspended in a small volume of the same (second) buffer and homogenized in a small volume homogenizer $(1 \mathrm{ml})$ to give a protein concentration of $35-$ $45 \mathrm{mg} / \mathrm{ml}$ as determined by the method of Lowry (16). Bovine serum albumin (BSA; Sigma fraction V) was used as a standard.

$\mathrm{Ca}^{2+}$ uptake movement in rat liver endoplasmic reticulum vesicles (microsomes): The assay mixture, routinely used for rat liver microsomes, contained in a final volume of $1 \mathrm{ml}: 150 \mathrm{mM}$ sucrose, $50 \mathrm{mM} \mathrm{KCl}, 10$ $\mathrm{mM}$ Hepes/KOH, $\mathrm{pH} 7.0,5 \%$ (w/v) polyethylene glycol, $1 \mathrm{mM}$ DTT, $2 \mathrm{mM} \mathrm{MgCl} 2,5 \mathrm{mM}$ ATP and an ATP regenerating system consisting of $50 \mu \mathrm{g} / \mathrm{ml}$ creatine phosphokinase and $5 \mathrm{mM}$ phosphocreatine. An ATP regenerating system allows a greater degree of $\mathrm{Ca}^{2+}$ uptake. The temperature was $30^{\circ} \mathrm{C}$ and uptake was started by the addition of $1.2 \mathrm{mg} / \mathrm{ml}$ microsomal protein. The movements of $\mathrm{Ca}^{2+}$ were determined by using Fluo-3 dye. $1 \mu \mathrm{M}$ Fluo-3 (pentammonium salt) was added to the assay medium before starting $\mathrm{Ca}^{2+}$ uptake. All fluorescence measurements were made using a Shimadzu RF-5000 fluorimeter. A magnetic stirring device ensured quick and complete mixing of any additions. To show the effects of TGC for rapid and complete $\mathrm{Ca}^{2+}$ release from rat liver microsomes and it's dose-dependent effect, both single $(64 \mathrm{nM})$ and complementary amounts $(1.6 \mathrm{nM}, 8$ $\mathrm{nM}, 16 \mathrm{nM}, 38.4 \mathrm{nM})$ of TGC were added into the separate sets of assay mixtures. With the omission of ATP regenerating system, the dose-dependent effect of TGC were also tested for the microsomal protein concentration by using microsomes at both low $(0.56$ $\mathrm{mg} / \mathrm{ml})$ and high $(1.12 \mathrm{mg} / \mathrm{ml})$ concentrations, with the range of 0-16 $\mathrm{nM}$ TGC and 0-64 $\mathrm{nM} \mathrm{TGC}$, respectively. The initial rate of $\mathrm{Ca}^{2+}$ uptake was expressed as nmol $\mathrm{Ca}^{2+} / \mathrm{mg} / \mathrm{min}$. The number of experiments (or liver used) (n) $=7$.

Determination of ATPase activity by using rat liver endoplasmic reticulum vesicles (microsomes): The ATPase activity of the microsomal fraction was determined by measurement of Pi release from ATP according to Dawson and Fulton (10). The incubation mixture contained in a final volume of $1 \mathrm{ml}: 100 \mathrm{mM}$ $\mathrm{KCl}, 20 \mathrm{mM}$ Hepes/KOH, pH 7.0, $5 \mathrm{mM} \mathrm{MgCl} 2,1 \mu \mathrm{g} / \mathrm{ml}$ $\mathrm{A} 23187,50 \mu \mathrm{M} \mathrm{CaCl}_{2}$ (to give the required free $\mathrm{Ca}^{2+}$ concentration, approximately $5 \mu \mathrm{M}$ ) and $0.7-2.0 \mathrm{mg}$ of microsomal protein. This medium describes the 'plus $\mathrm{Ca}^{2+}$ conditions', whereas the 'minus $\mathrm{Ca}^{2+}$ conditions' only differ in so far as added $\mathrm{Ca}^{2+}$ was excluded and replaced by $1 \mathrm{mM}$ EGTA (free $\mathrm{Ca}^{2+}<1 \mathrm{nM}$ ). For both plus and minus $\mathrm{Ca}^{2+}$ conditions, the $\mathrm{Ca}^{2+}$-ATPase activity of rat liver microsomes were detected for a range of 0 $320 \mathrm{nM}$ TGC concentrations, with number of experiments (or liver used) (n) $=7$ and 4 , respectively. After pre-incubation at $37^{\circ} \mathrm{C}$ for $5 \mathrm{~min}$., the reaction was started by the addition of $1 \mathrm{mM}$ ATP. After incubation $\left(37^{\circ} \mathrm{C}, 10 \mathrm{~min}.\right)$, the reaction was terminated by the addition of $0.5 \mathrm{ml}$ of $5 \%(\mathrm{w} / \mathrm{v})$ cold trichloroacetic acid (TCA). The resultant precipitate was centrifuged using a bench centrifuge (Sigma 3K10-Howe) and $1 \mathrm{ml}$ of the supernatant was removed. The inorganic phosphate was measured by a method described by Fiske and Subbarow (11). Blanks were also used to set up the spectrophotometer and samples were read at $660 \mathrm{~nm}$.

\section{Results}

Thapsigargicin-induced $\mathrm{Ca}^{2+}$ release from rat liver microsomes: Addition of thapsigargicin ( $\left.\mathrm{TGC}^{\mathrm{a}} ; 64 \mathrm{nM}\right)$ to $\mathrm{Ca}^{2+}$ loaded rat liver microsomes results in the rapid and complete release of the sequestered $\mathrm{Ca}^{2+}$ (Figure $2 \mathrm{~A})$. This result is consistent with the thapsigargininduced $\mathrm{Ca}^{2+}$ release data described by Thastrup et al. (27). The effects of complementary amounts of TGC $\left(\mathrm{TGC}^{\mathrm{b}, \mathrm{c}, \mathrm{d}, \mathrm{e}}\right)$ can be seen in Fig. 2B. According to this figure it is possible to suggest that, like thapsigargin, TGC has a dose-dependent kind of effect on $\mathrm{Ca}^{2+}$ release from microsomes. As it can also be seen from the same figure, after releasing all sequestered $\mathrm{Ca}^{2+}$ from the TGCreleasable pool, additional amounts of TGC, even maximum concentrations $\left(\mathrm{TGC}^{\mathrm{a}}\right)$, do not cause any further $\mathrm{Ca}^{2+}$ release from the vesicles even though a 
small further release is given by A23187. Therefore it is possible to suggest that for rat liver endoplasmic reticulum microsomes, thapsigargicin appears to cause irreversible $\mathrm{Ca}^{2+}$ release, maximal release is given by 64 $\mathrm{nM}$. The comparison of the data from Figure $2 \mathrm{~B}$ together with the results shown in Figure 3, reinforce the idea of the dose-dependence of $\mathrm{TGC}$ on $\mathrm{Ca}^{2+}$ release from microsomes. Figure 3 also shows that the concentration of TGC required to cause $\mathrm{Ca}^{2+}$ uptake depends on the microsomal protein concentration. At low protein concentrations $(0.56 \mathrm{mg} / \mathrm{ml})$ the dose-response curve shifts to the left. This suggests that, like TG, TGC is a very high affinity inhibitor which binds stoichiometrically to its target.
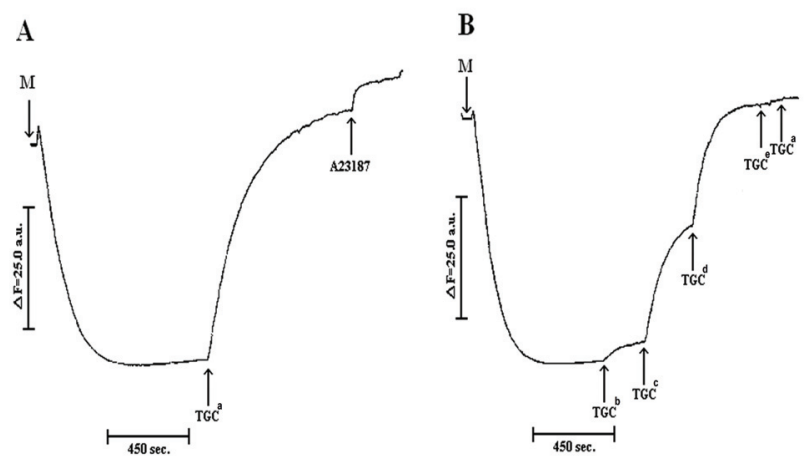

Figure 2. Thapsigargicin-induced $\mathrm{Ca}^{2+}$ movements in rat liver microsomes. In $\mathbf{A}, 64 \mathrm{nM}$ thapsigargicin $\left(\mathrm{TGC}^{\mathrm{a}}\right)$ was added at 6 min. after initiating $\mathrm{Ca}^{2+}$ uptake upon addition of $1 \mathrm{mg} / \mathrm{ml}$ microsomes (M), as indicated by the arrows. Complete store depletion was facilitated by addition of A23187 $(1 \mu \mathrm{g} / \mathrm{ml})$ at the time indicated by the arrow. $\mathbf{B}$, the same as $\mathbf{A}$, however complementary amounts of thapsigargicin $\left(\mathrm{TGC}^{\mathrm{b}} ; 1.6 \mathrm{nM}\right.$, $\mathrm{TGC}^{\mathrm{c}} ; 8 \mathrm{nM}, \mathrm{TGC}^{\mathrm{d}} ; 16 \mathrm{nM}, \mathrm{TGC}^{\mathrm{e}} ; 38.4 \mathrm{nM}$ ) was added after initiating $\mathrm{Ca}^{2+}$ uptake. For $\mathbf{A}$ and $\mathbf{B}$; number of experiments (or liver used) $(\mathrm{n})=7$.

Sekil 2. Siçan karaciğer mikrozomlarında tapsigargisinle indüklenmiş $\mathrm{Ca}^{2+}$ hareketleri. A, $1 \mathrm{mg} / \mathrm{ml}$ mikrozom (M) ilavesi sonucu $\mathrm{Ca}^{2+}$ alınımının başlaması ve 6 . dakikadaki $64 \mathrm{nM}$ tapsigargisin $\left(\mathrm{TGC}^{\mathrm{a}}\right)$ ilavesi oklarla gösterilmiştir. Deponun tamamen boşaltımı A23187 $(1 \mu \mathrm{g} / \mathrm{ml})$ ilavesiyle sağlanmış olup, ok ile gösterilmiştir. $\mathbf{B}, \mathbf{A}$ ile aynıdır, bununla birlikte $\mathrm{Ca}^{2+}$ alınımının başlamasını takiben tapsigargisinin komplementer miktarları (TGC ${ }^{\mathrm{b}}$; $1.6 \mathrm{nM}, \mathrm{TGC}^{\mathrm{c}} ; 8 \mathrm{nM}, \mathrm{TGC}^{\mathrm{d}} ; 16 \mathrm{nM}, \mathrm{TGC}^{\mathrm{e}}$; $38.4 \mathrm{nM}$ ) eklenmiştir. A ve $\mathbf{B}$ için; deney sayısı (ya da kullanılan karaciğer sayısı) (n) $=7$ 'dir.

Inhibitory effect of TGC on $\mathrm{Ca}^{2+}$-ATPase activity: The ability of TGC to release nearly all sequestered $\mathrm{Ca}^{2+}$ and completely inhibit $\mathrm{Ca}^{2+}$ loading of rat liver microsomes (Figure 2) suggests that TGC may inhibit ER $\mathrm{Ca}^{2+}$-ATPase activity. Figure 4 shows TGC inhibits $\mathrm{Ca}^{2+}$-ATPase activity in rat liver microsomes. The potency is similar to the potency of stimulation of $\mathrm{Ca}^{2+}$ release, with $50 \%$ inhibition of $\mathrm{Ca}^{2+}$-stimulated ATPase by $<50$ nM TGC (Figure 4).

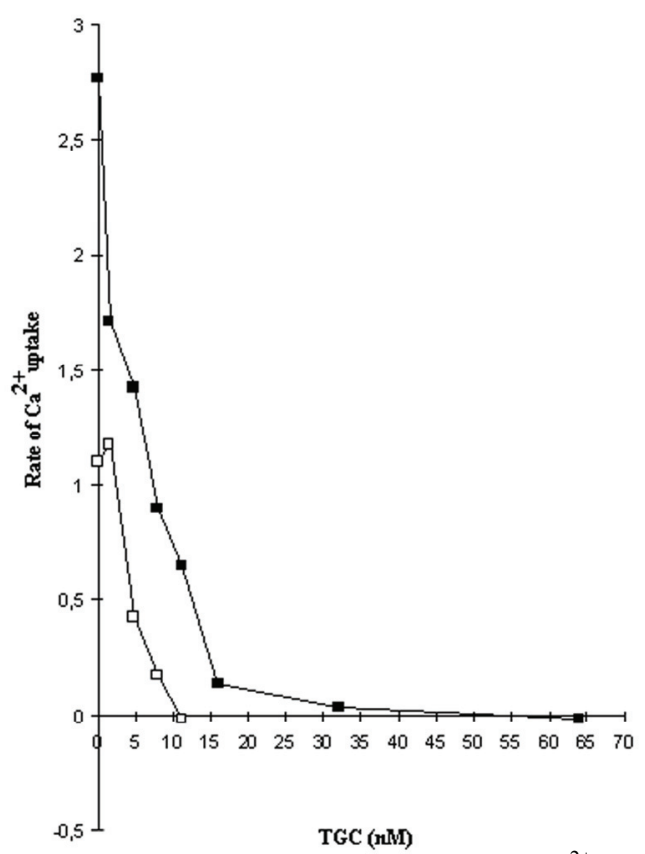

Figure 3. Dose-dependent effects of TGC on $\mathrm{Ca}^{2+}$ uptake from microsomes. In figure, ( $\mathbf{-})$ represents the rate of $\mathrm{Ca}^{2+}$ release from rat liver endoplasmic reticulum vesicles $(1.12 \mathrm{mg} / \mathrm{ml})$ for a range of 0-64 nM TGC concentration. ( $\square)$, the same as ( $\square)$, but amount of microsomes used were $0.56 \mathrm{mg} / \mathrm{ml}$ with the range of TGC from 0-16 nM. For $\square$ and $\mathbf{m}$; number of experiments (or liver used) $(\mathrm{n})=7$.

Şekil 3. Mikrozomlardan $\mathrm{Ca}^{2+}$ alınımı üzerine TGC'nin doza bağımlı etkileri. Şekilde, 0-64 nM arası değişen farklı TGC konsantrasyon aralıkları için endoplazmik retikulum veziküllerinden $(1.12 \mathrm{mg} / \mathrm{ml}) \mathrm{Ca}^{2+}$ salınımı hızı (a) ile gösterilmiştir. (ם), (घ) ile aynıdır, ancak kullanılan mikrozom $0.56 \mathrm{mg} / \mathrm{ml}$ olup, TGC konsantrasyonu ise $0-16 \mathrm{nM}$ aralığında değişmektedir. $\square$ ve için; deney sayısı (ya da kullanılan karaciğer sayısı) (n) = 7'dir.

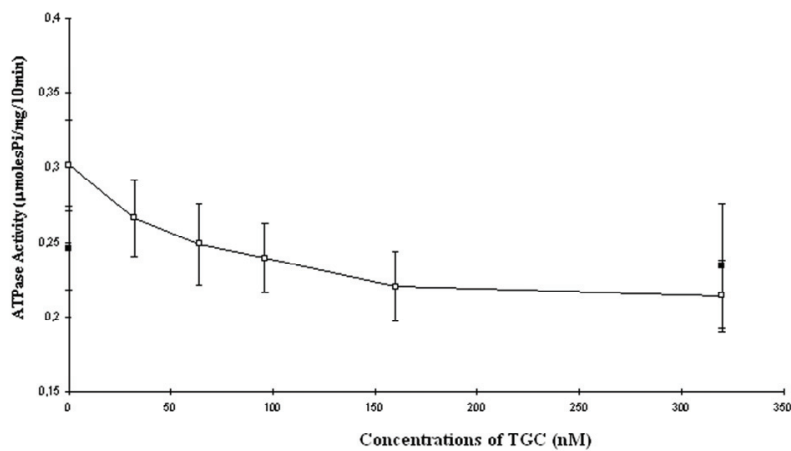

Figure 4. Inhibition of $\mathrm{Ca}^{2+}$-ATPase activity by TGC in the presence $(\square)$ and absence $(\square)$ of $\mathrm{Ca}^{2+}$. In figure, ( $\square$ ) represents the $\mathrm{Ca}^{2+}$-ATPase activity of rat liver microsomes for a range of $0-320 \mathrm{nM}$ thapsigargicin (TGC) concentration in the presence of $\mathrm{Ca}^{2+} .(\square)$, the same as ( $\left.\square\right)$, but in the absence of $\mathrm{Ca}^{2+}$ in the assay medium. Each value represents the Mean \pm S.D. For $\square$; number of experiments (or liver used) ( $\mathrm{n})=7$ and for $\boldsymbol{\square} ; \mathrm{n}=4$. Şekil 4. $\mathrm{Ca}^{2+}$-ATPaz aktivitesinin $\mathrm{Ca}^{2+}$ un varlığında (口) ve yokluğunda (匹) TGC ile inhibisyonu. Şekilde, $\mathrm{Ca}^{2+}$ varlığında sıçan karaciğer mikrozomlarındaki $\mathrm{Ca}^{2+}$-ATPaz aktivitesi 0-320 $\mathrm{nM}$ arası değişen farklı TGC konsantrasyon (TGC) aralıkları

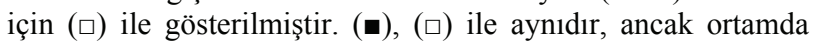
$\mathrm{Ca}^{2+}$ yoktur. Her bir değer Ortalama \pm Standard Sapma'y1 temsil etmektedir. $\square$ için; deney sayısı (ya da kullanılan karaciğer sayısı) (n) = 7 ve $\boldsymbol{\|}$ için; $\mathrm{n}=4$ 'tür. 


\section{Discussion and Conclusion}

The network of $\mathrm{Ca}^{2+}$ channels and pumps permits the movement of $\mathrm{Ca}^{2+}$ between the cytoplasmic space and the extracellular fluid and between the cytoplasmic space and intracellular $\mathrm{Ca}^{2+}$ stores. As a result of this arrangement a fine control of $\left[\mathrm{Ca}^{2+}\right] \mathrm{i}$ is obtained by $\mathrm{Ca}^{2+}$ ATPases.

On the other hand, the inhibitors of intracellular $\mathrm{Ca}^{2+}$-ATPases constitute a quite interesting and useful group of chemical compounds inasmuch as they provide important means of probing the catalytic and transport mechanism of these transport enzymes, their expression and regulation in cells and the role of cytosolic $\mathrm{Ca}^{2+}$ stores in cell biology.

Thapsigargin was shown in a number of cell types to increase $\left[\mathrm{Ca}^{2+}\right] \mathrm{i}$ by inducing a rapid and dosedependent $\mathrm{Ca}^{2+}$ release from intracellular $\mathrm{Ca}^{2+}$ stores without hydrolysis of phosphoinositides $(26,28)$. From the findings of Cullen et al. (7) and Caspersen and Treiman (4), it has been suggested that thapsigargin (TG) discharges intracellular stores by an acute and highly specific inhibition of the SERCA ATPases at subnanomolar concentrations (15). Therefore, a number of laboratories have reported that thapsigargin specificially inhibits SERCA ATPases $(17,25,27)$ with little or no effect on the $\mathrm{Ca}^{2+}$-ATPases of hepatocyte or erythrocyte PMCA (23).

The finding of a highly potent inhibition of the $\mathrm{Ca}^{2+-}$ activated microsomal ATPase indicates that the molecular target for thapsigargin is the $\mathrm{Ca}^{2+}$ accumulation system rather than the efflux system. A similar dose dependency of the thapsigargin-induced $\mathrm{Ca}^{2+}$ release and pump inhibition, together with the ability of ATP depletion to elicit an identical release, provides strong evidence for identification of the ER $\mathrm{Ca}^{2+}$ ATPase as the site of thapsigargin action.

Very recently, the effect of TGC on $\mathrm{Ca}^{2+}$ movements has been investigated by using both digitonin-permeabilized and intact L1210 mouse lymphoma cells (22). It has been found that the TGC behaves exactly similar to TG in these cells too.

From the structural smilarities between TGC and TG, their origination from the same Thapsia genus and by the results of our current study, it is just a conclusion that in this system (microsomes) TGC behaves like TG. TGC has the ability to increase the intracellular free $\mathrm{Ca}^{2+}$ concentration $\left(\left[\mathrm{Ca}^{2+}\right] \mathrm{i}\right)$ by discharging the intracellular $\mathrm{Ca}^{2+}$ stores and causing a potent and specific inhibition of the ER $\mathrm{Ca}^{2+}$-ATPase.

\section{Acknowledgment}

Author is grateful to Emeritus Professor Alan P. Dawson for his helpful advices and discussions. During this study, author was supported by the bursary from Turkish Ministry of National Education (MEB).

\section{References}

1. Benech JC, Wolosker H, de Meis L (1995): Reversal of the $\mathrm{Ca}^{2+}$ pump of blood platelets. Biochem J, 306, 35-38.

2. Carafoli E (2002): Calcium signaling: A tale for all seasons. PNAS, 99, 1115-1122.

3. Carafoli E, Santella L, Branca D, Brini M (2001): Generation, Control, and Processing of Cellular Calcium Signals. Crit Rev Biochem Mol Bio, 36, 107-260.

4. Caspersen C, Treiman M (1995): Thapsigargin discriminates strongly between $\mathrm{Ca}^{2+}$-ATPase phosphorylated intermediates with different subcellular distributions in bovine adrenal chromaffin cells. FEBS Lett, 377, 31-36.

5. Christensen SB (1988): Interpretation of the NMR and circular dichroic data of the sesquiterpene lactone thapsigargin. Acta Chem Scand, B42, 623-628.

6. Christensen SB, Andersen A, Poulsen JC, Treiman M (1993): Derivatives of thapsigargin as probes of its binding site on endoplasmic reticulum $\mathrm{Ca}^{2+}$ ATPase: Stereoselectivity and important functional groups. FEBS Lett, 335, 345-348.

7. Cullen PJ, Irvine RF, Drobak BK, Dawson AP (1989): Inositol 1,3,4,5-tetrakisphosphate causes release of $\mathrm{Ca}^{2+}$ from permeabilized mouse lymphoma L1210 cells by its conversion into inositol 1,4,5-trisphosphate. Biochem J, 259, 931-933.

8. Dawson AP (1982): Kinetic properties of the $\mathrm{Ca}^{2+}$ accumulation system of a rat liver microsomal fraction. Biochem. J, 206, 73-79.

9. Reinhart PH, Bygrave FL (1981): Glucagon stimulation of ruthenium red-insensitive calcium ion transport in developing rat liver. Biochem J, 194, 541-549.

10. Dawson AP, Fulton DV (1983): Some properties of the $\mathrm{Ca}^{2+}$-stimulated ATPase of a rat liver microsomal fraction. Biochem J, 210, 405-410.

11. Fiske CH, Subbarow Y (1925): The colorimetric determination of phosphorus. J Biol Chem, 66, 375-400.

12. Goeger DE, Riley RT, Dorner JW, Cole RJ (1988): Cyclopiazonic acid inhibition of the $\mathrm{Ca}^{2+}$-transport ATPase in rat skeletal muscle sarcoplasmic reticulum vesicles. Biochem Pharmacol, 37, 978-981.

13. Holzapfel CW (1968): The isolation and structure of cyclopiazonic acid, a toxic metabolite of penicillium cyclopium westling. Tetrahedron, 24, 2101-2119.

14. Jackson TR, Patterson SI, Thastrup O, Hanley MR (1988): A novel tumour promoter, thapsigargin, transiently increases cytoplasmic free $\mathrm{Ca}^{2+}$ without generation of inositol phosphates in NG115-401L neuronal cells. Biochem J, 253, 81-86.

15. Ley SV, Antonello A, Balskus EP, Booth DT, Christensen SB, Cleator E et al. (2004): Synthesis of the thapsigargins. PNAS, 101, 12073-12078.

16. Lowry OH, Rosebrough NJ, Farr AL, Randal RJ (1951): Protein measurement with the folin phenol reagent. J Biol Chem, 248, 265-275.

17. Lytton J, Westlin, M, Hanley MR (1991): Thapsigargin inhibits the sarcoplasmic or endoplasmic reticulum $\mathrm{Ca}$ ATPase family of calcium pumps. J Biol Chem, 266, 17067-17071.

18. MacLennan DH, Brandl CJ, Korczak B, Green NM (1985): Amino-acid sequence of a $\mathrm{Ca}^{2+}+\mathrm{Mg}^{2+}$-dependent ATPase from rabbit muscle sarcoplasmic reticulum, 
deduced from its complementary DNA sequence. Nature, 316, 696-700.

19. Moore GA, McConkey DJ, Kass GE, O'Brien PJ, Orrenius S (1987): 2,5-Di(tert-butyl)-1,4-benzohydroquinone - a novel inhibitor of liver microsomal $\mathrm{Ca}^{2+}$ sequestration. FEBS Lett, 224, 331-336.

20. Murphy SJ, Schroeder RE, Blacker AM, Krasavage WJ, English JC (1992): A Study of Developmental Toxicity of Hydroquinone in the Rabbit. Fundam Appl Toxicol, 19, 214-221.

21. Niggli V, Adunyah ES, Carafoli E (1981): Acidic phospholipids, unsaturated fatty acids, and limited proteolysis mimic the effect of calmodulin on the purified erythrocyte $\mathrm{Ca}^{2+}$-ATPase. J Biol Chem, 256, 8588-8592.

22. Oztetik, E. (2009): Effects of Thapsigargicin on $\mathrm{Ca}^{2+}$ Movements in L1210 Cells Permeabilized with Digitonin. Biochemistry-Moscow Suppl Series B: Biomed Chem, 3, 156-163.

23. Papp B, Enyedi A, Kovacs T, Sarkadi B, Wuytack F, Thastrup O et al. (1991): Demonstration of two forms of calcium pumps by thapsigargin inhibition and radioimmunoblotting in platelet membrane vesicles. J Biol Chem, 266, 14593-14596.

24. Rasmussen U, Christensen SB, Sandberg F (1978): Thapsigargin and thapsigargicin, two new histamin liberators from Thapsia garganica L. Acta Pharm Suec, 15, 133-140.

25. Sagara, Y., Fernandez-Belda, F., de Meis, L. and Inesi, G. (1992): Characterization of the inhibition of intracellular $\mathrm{Ca}^{2+}$ transport ATPases by thapsigargin. J Biol Chem, 267, 12606-12613.
26. Takemura H, Hughes AR, Thastrup O, Putney JW (1989): Activation of calcium entry by the tumor promoter thapsigargin in parotid acinar cells. Evidence that an intracellular calcium pool and not an inositol phosphate regulates calcium fluxes at the plasma membrane. J Biol Chem, 264, 12266-12271.

27. Thastrup O, Cullen PJ, Drobak BK, Hanley MR, Dawson AP (1990): Thapsigargin, a tumor promoter, discharges intracellular $\mathrm{Ca}^{2+}$ stores by specific inhibition of the endoplasmic reticulum $\mathrm{Ca}^{2+}$-ATPase. PNAS 87, 2466-2470.

28. Thastrup O, Dawson AP, Scharff O, Foder B, Cullen PJ, Drobak BK (1989): Thapsigargin, a novel molecular probe for studying intracellular calcium release and storage. Agents Actions, 27, 17-23.

29. Toyoshima C, Nakasako M, Nomura H, Ogawa H. (2000): Crystal structure of the calcium pump of sarcoplasmic reticulum at 2.6 A resolution. Nature, 405, 647-655.

30. Wictome M, Michelangeli F, Lee AG, East JM (1992): The inhibitors thapsigargin and 2,5-di(tert-butyl)-1,4benzohydroquinone favour the $\mathrm{E} 2$ form of the $\mathrm{Ca}^{2+}, \mathrm{Mg}^{2+}$ ATPase. FEBS Lett, 304, 109-113.

Geliş tarihi: 28.04.2011 / Kabul tarihi: 17.11.2011

Address for correspondence: Assist. Prof. Dr. Elif ÖZTETIK Anadolu University, Science Faculty, Department of Biology, 26470 Eskisehir, Turkey E-mail: eoztetik@anadolu.edu.tr Tel: +90 222-3350580/4730

Fax: $+90222-3204910$ 